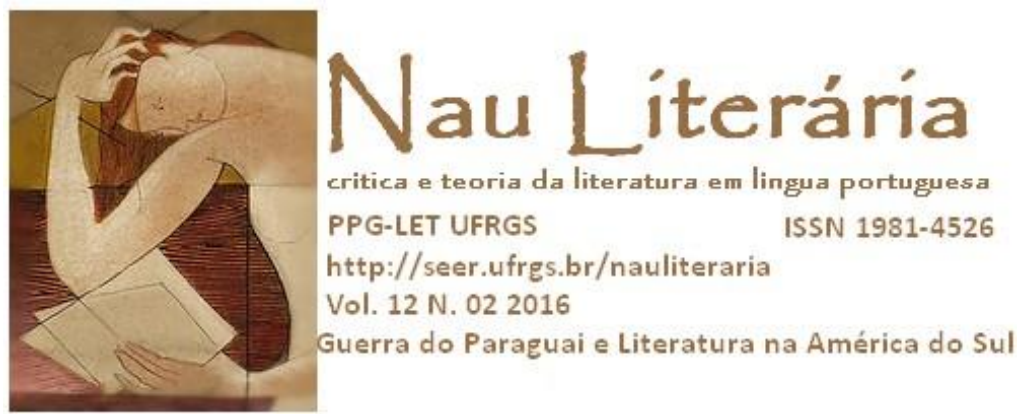

\title{
NAMBRENA, FALCATRUA E CURUZU NA GUERRA GUASÚ DA AMÉRICA DO SUL
}

\author{
Alai Garcia Diniz \\ UNILA
}

Resumo: Em um país pluriétnico como o Brasil, que não se assume como tal, foi permitindo o corte de árvores nativas; a extinção de pássaros e gerando violência (como a Guerra contra o Paraguai), tudo convida-me a ler resíduos, gestos e práticas culturais heterogêneas. Assim, entro no campo, tanto do arquivo (diário de Taunay ou carta de um militar no Forte Curuzu de 1866) como do repertório, a partir da proposta de Diana Taylor, 2013. É quando me permito expandir a leitura para a tela de Cándido Lopez, argentino a um documentário atual Guataha, 2015, pois entre o passado bélico e as batalhas entre aldeia indígena e hidroelétrica nada mais há que um estopim para a leitura da violência na contemporaneidade. De Cándido Lopez ao documentário Guataha as passagens propõem articular um aparato de ler que, como um passeio guarani, invada a fronteira com um movimento de descolonização do conhecimento.

\section{Palavras chave: Guerra Guasú; Literatura; Pintura; Taunay; Candido Lopez,Guataha}

Abstract: In a country pluriethnical such as Brazil, that does not accept itself as such, the cutting of native trees was permitted; as was the extinction of birds and generating violence (such as the War on Paraguai), it all invites me to read residue, and heterogeneous cultural practices. Thus, I enter the field, both of archive (the diary of Taunay or the letter of a military man in Fort Curuzu from 1866) as well as repertoire, through what proposes Diana Taylor, 2013. That is when I allow myself to expand the reading to the screen of Cándido Lopez, Argentine, to a current documentary Guataha, 2015, for between the war past and the battles between native tribes and a hydroelectric power plant there is nothing more than a trigger for the reading of violence in contemporaneity. From Cándido Lopez to the documentary Guataha the passages propose to articulate an apparatus of reading that, as a Guarani tour, can invade the border with a motion o decolonization of knowledge.

Keywords: Guasú War; Literature; Painting; Taunay; Candido Lopez, Guataha

Para entender nós temos dois caminhos: o da sensibilidade que é o entendimento do corpo; e o da inteligência que é o entendimento do espírito. Eu escrevo com o corpo. (Manoel de Barros, 2013)

Tañanemanduamemeke chamõi Guilhemore [Lembraremos sempre do xamã Guilherme]

(Inscrição em foto do líder da comunidade Tekoha Ocoy, de S. Miguel do Iguaçu,

PR.2015).

\section{Preâmbulo}


Analisando à distância, nesse mundo desacostumado da presença, que de futuro tem a virtualidade dos ataques massivos, revejo como, há dezoito anos, minha tese de doutorado tentava fazer do século XIX uma miragem da modernidade que, em minha perspectiva, se manifestava com uma presença obsessiva de corpos na construção simbólica de uma guerra que abrangia diferentes sentidos. Ao tentar decompor os corpos da Guerra contra o Paraguai, enveredei por um caminho interdisciplinar, o qual foi impossível abandonar. Desacreditando de totalizações, adivinhando algumas problemáticas que suscitavam minha imaginação em busca de transversalidades, considerei a montagem do corpo bélico em uma pluralidade de perspectivas que ia da estética à política, da militarização do corpo masculino ao cotidiano e em diferentes classes de produtos simbólicos que iam se desdobrando, conforme lia os corpos. O de vanguarda; o corpo aliado; o inimigo; o corpo negro; o guarani; o corpo da retaguarda, o corpo "mala" (feminino).

O estudo do tema bélico no imaginário interfronteiriço sugere um passeio por um desencontro intercultural trágico que é como pensar no passado como um país estrangeiro $^{1}$ (apud SALLINS, 2006, p. 10), mas a partir de uma perspectiva multimodal da literatura que se torna indisciplinada e se aventura pelas veredas da interdisciplinaridade. Entre diferentes suportes, é possível combinar um produto de arquivo como uma das partes, (a quarta) das memórias de Alfredo D’Escragnolle Taunay, o tenente que virou visconde. Já devidamente reconhecida, com uma epístola de um soldado brasileiro encontrada em um baú familiar, inédita e desses arquivos ao repertório. Conceito este que para Diana Taylor faria a diferença por sua repetição coletiva, visualização receptiva e efemeridade, como o é uma arte da presença; hic et nunc. arte de pé, de mão, de voz, o canto numa arte do corpo: ritual; visual? Operar a partir do repertório de práticas incorporadas que implicam um sistema de criação e transmissão de conhecimento (cf. TAYLOR, 2013, p. 57) performances; pinturas, filmes, e até mesmo a escritura performática como propõe Graciela Ravetti para pensar a literatura contemporânea. Enveredar por diferentes línguas. Seu corpus originário ou em deslocamento, tal como a diglossia que perpetua um conflito surdo entre o Guarani e a língua castelhana da colonização. Ou na reinvenção da linguagem desde a vanguarda de Xul Solar à ficção de Wilson Bueno com Mar Paraguaio. Ou no poema de Douglas Diegues e de Jorge Kanese cuja poética é a de brincar com o limite dos idiomas, com o

\footnotetext{
${ }^{1}$ Epígrafe do romance The Go Between de Lesley Poles Hartley (1895-1972) e da obra do historiador David Lowental - The Past is a foreign country, Cambridge United press, 1985.
} 
que não é mais uma alusão; código sempre insuficiente que para Kanese é uma pornovanguarda que aborta a ideia do poema como canto. E para falar só desta fronteira trinacional (Argentina, Brasil, Paraguai) que, além de envolver três dos quatro países que sofreram as consequências da Guerra da Tríplice Aliança no imaginário interfronteiriço, vem a ser a que reconheço como a mais próxima. O passeio poderia começar com a referência à bioética guarani e a um de seus conceitos fundamentais.

\section{Primeiro Ato - Bioética Guarani e a memória da Campanha da}

\section{Cordilheira}

Entender como a filosofia do presente recupera o pensamento de um território invisível e aprofunda a racionalidade captada através de outras práticas culturais como a oralidade (rituais; relações interculturais e manifestações residuais) é a proposta do diálogo que tem como metodologia, entre outros materiais, as performances como categoria analítica. No caso da contribuição da obra Nambréna (2009) de José Manuel Silvero, há uma constatação contundente que não só observa o desprezo (el ninguneo) pela produção intelectual da terra guarani, como também elabora um discurso abrangente sobre as relações entre a colonização do saber e do poder, marca indelével que a colonização deixou na pele da América do Sul.

Em primeiro lugar, pelo modo como se agruparam as culturas indígenas; um meio subliminar de reduzir a força daqueles aos que a catequese pretendia cooptar. Após o agrupamento, vem a reforma pombalina que causa a dispersão da Companhia de Jesus no século XVIII. No Cone Sul, após a independência, na segunda metade do século XIX, a pele que a colonização marcou, com a Guerra Guasú atinge seu ventre, o que até hoje reverbera em discursos, em perspectivas ou em limiares obscurantistas a de uma carga deixada pelo imaginário bélico.

Considerando que, a partir do fictício e do imaginário, vasculhar a memória implica trazer à baila esses dois elementos que consolidam o artefato artístico literário, fílmico ou performático, se não o cultural, permito-me cruzar a ponte que, criada pelo eufemismo da amizade, serviu, de fato, em primeiro lugar, para abrigar a repressão, o contrabando e a violência, e do lado paraguaio, hoje revela um estudo de José Manuel Silvero, filósofo disposto a refletir sobre os conceitos que configuram, historicamente, as relações intersubjetivas no universo paraguaio, descortina um termo arrematado de uma coloquialidade diglóssica no Paraguai: nambrena, vocábulo devorado pelo guarani 
que viria da expressão "No hombre!" em uma frase que a elite colonizadora mostrava o desprezo aos indígenas.

Entretanto, claro que isso não determinou a Guerra Guasú, mas confirmou a carência de uma diplomacia respeitosa do Brasil em relação a Solano López que se dispôs a mediar o conflito no Uruguai alguns meses antes. Entre ditaduras amigas houve silêncio que ocultou o próprio centenário da Guerra Guasú e hoje surge nos ecos de uma atualidade que troca El trueno entre las hojas (1953) para El trueno de la soja (o trovão da soja). Assim como a repercute a mais antiga reportagem interfronteiriça e testemunhal de Rafael Barrett sobre a escravidão nos ervais que em 1908 foi publicada como "Lo que son los yerbales" em um jornal assunceno e agora se recria outro tipo de opressão em "lo que son los sojeros" (sojeiros). O certo é que Silvero com námbrena não realiza apenas uma crítica local, em uma escritura performática, mas afirma-se como intelectual intercultural, ao criticar que o discurso funciona como um espaço em que se mede o poder de silenciar o pensamento em nome da citação alheia, pois a linguagem detém o poder sobre os corpos e se converte em um de seus aparatos mais potentes. Essa ideia de Silvero combina com o que pensa Rodolfo Kush sobre a educação latino-americana que leva à desconstituição do sujeito. O propósito de reclamar um discurso abrangente faz com que sua busca se aprofunde em algo mais amplo que os limites da nacionalidade paraguaia e o autor usa com o conceito de nambrena a "terra guarani" como um modo de expandir o que historicamente se constituiu como imagem do Paraguai aos vizinhos: "uma ilha rodeada de terras por todos os lados" (Roa Bastos) ou uma "incógnita" (Alberto Sánchez, 1937) a uma comunidade leitora transnacional com a proposta de operar, alavancar o direito à diferença! Operar filosoficamente com um conceito que busca no terreno da oralidade e da conversa corriqueira, um termo coloquial cuja etimologia corromperia um insulto histórico a base de um sintagma: "No hombre" que, se origina no âmbito colonial e das relações hierarquizadas e interétnicas. A injúria usada pelo colonizador; padre ou encomendero que servia para criticar os equívocos cometidos pelos indígenas durante o trabalho: "No hombre! (Não é homem não!)", ao longo dos séculos vai adquirindo um matiz coloquial com a presença do guarani e que realiza no espanhol paraguaio uma fórmula particular de interjeição que se aglutina em: Nambréna!

E é aí que entra a associação com a Guerra Grande. Sem querer aqui inventar a roda dos temas que culminaram nas invasões de territórios, é preciso relembrar que havia interesses na definição dos limites que, por sua vez, em 1865, ao configurar-se a 
aliança entre dois grandes (Argentina, Brasil) era possível controlar uma bipolaridade hegemônica (como afirma Gerardo Caetano) ${ }^{2}$ que por sua vez neutralizava os pequenos países da Bacia do Prata (Uruguai e Paraguai).

Como o objeto da história são os seres humanos no tempo, implica uma relação fundamental entre compreender o presente pelo passado e vice versa (RICOEUR, 2007, p. 180). Também há o fato de que se a história estabelece com seu leitor um pacto de veracidade, a literatura apenas propõe um desejo ou a ficção como suspeita e ao relacionar um produto a um lugar, a primeira tarefa para ler a história, segundo Certeau, “o não dito do lugar de onde fala o historiador" (apud RICOEUR, 2007, p. 177). Interpelar a história, anunciar os indícios, confrontar os testemunhos e interpelar o imaginário que alimentam discursos; partir de controvérsias apresenta-se como o estranhamento discursivo, próprio desse olhar perante o fato e o desejo. No caso da primeira guerra sul-americana, em cada pólo do conflito há um nome para o mesmo conflito bélico. Assim, Guerra do Paraguai, no Brasil dataria de novembro de 1864, com o apresamento por parte de Solano López do navio brasileiro "Marquês de Olinda" que subia o Rio Paraguai, única via de acesso ao Mato Grosso, que vinha sendo uma das fontes de disputa, devido a limites imprecisos. Em dezembro, após o decreto da guerra ao Brasil, o exército paraguaio invade o Mato Grosso. Isto ocorre cinco meses depois que Solano López remete ao governo imperial uma nota para ser mediador entre D. Pedro II que havia invadido o Uruguai para garantir a supremacia de Venâncio Flores, também apoiado pela Argentina que depôs o governo institucional de Aguirre, presidente do Uruguai. Apesar de reforçar a intenção de negociar o problema da emancipação dos países menores na região do Rio da Prata com uma proposta direta ao ministro Saraiva, que "achava sem objeto a mediação oferecida" (apud JOURDAN, 1890, p. 28). - Nambrena! Solano López reage à resposta como demonstração de prepotência de parte do império brasileiro.

Entre diferentes controvérsias nem o problema de acesso ao mar por parte do governo paraguaio; ou as questões de limites entre Argentina e Paraguai sobre a região de Misiones e o Chaco, e com o Brasil a questão do Mato Grosso justificam a guerra politicamente incorreta levada a cabo por tanto tempo contra um só país. A Guerra da Tríplice Aliança evoca o pacto de primeiro de maio entre Brasil, Argentina e Uruguai que ocorre após a invasão das tropas paraguaias a Corrientes, em abril de 1865. Guerra

\footnotetext{
${ }^{2}$ Apud Lorena Soler, 2012, p. 6.
} 
del Paraguai contra la Triple Alianza era o modo como a historiografia tratou o conflito no Paraguai, entretanto com o tempo e as consequências catastróficas em termos demográficos, especialmente a população masculina gerou o termo Guerra Guasú.

Entre a entrada em Assunção em março de 1869 e a mudança na organização da guerra com a chefia de Conde D’Eu ao fim de março de 1870 para a caçada à Solano López, chamada eufemisticamente de Campanha da Cordilheira. O tenente que já havia participado antes na etapa da defesa do Mato Grosso no início do conflito em que os engenheiros aproveitaram para mapear a região e a guerra para Taunay havia se tornado um modo de transformar seu relato em literatura de viagem de coleta e pesquisa da fauna e da flora, o responsável pelo Diário do Exército, nas horas vagas deixava suas memórias com a observação de que só poderia ser publicadas cinquenta anos após sua morte. Nesta etapa final da perseguição há hegemonia brasileira com um total de 26.020 soldados, com 4 mil argentinos, 600 uruguaios contra um exército que não chegaria a cinco mim almas entre os quais mulheres e crianças.

Nesse período das Memórias de (Visconde) de Taunay (1869-1870) há um projeto testemunhal sobre os acontecimentos do último bloco da Guerra Guasú, no discurso que oficializa a voz imperial e a partir de uma perspectiva de superioridade militar, verticalizada e sem conflito direto com o rumo que toma a guerra na luta contra "paraguaiozinhos". Entremeados a depoimentos pessoais sobre as batalhas na posição de quem vive o perigo, é possível recolher os comentários sobre Solano López, Marechal que aqui aparece com o epíteto de "El Supremo"; aposto eficaz para reforçar a ideia de uma linhagem ditatorial representada pela trilogia que parte de Rodriguez de Francia, este sim, reconhecido como “El Supremo” e que governou o Paraguai de 1814 a 1840. A trilogia herdaria o apelido, pois sucedera Francia no "trono", Carlos Antonio López (pai de Solano) e em 1862, assume o poder Solano López. Nesses relatos é possível observar como se discrimina verbalmente ou em gravuras, ambos os lados da liderança inimiga.

Aqui cabe destacar que as relações assimétricas entre Argentina e Brasil com relação aos países menores (Uruguai, Paraguai) que já vinham sendo abaladas após a independência e muito tempo antes da guerra e no caso paraguaio, destaca-se o modo como a diplomacia brasileira se negava a admitir um mínimo de respeito estratégico para manter o equilíbrio regional. Por esta razão que em recentes estudos não é possível deixar de ressaltar a bipolaridade hegemônica do Brasil e Argentina diante de seus 
vizinhos. Como porta-voz da civilização, Taunay alude a uma "gente bruta e fanatizada" (TAUNAY, 2004, p. 436) que morre, na batalha de Ñu Guasú (Campo Grande, mais de dois mil paraguaios enquanto a perda do exército aliado foi de 411), só admite depois de narrar a batalha associar o número de mortos do inimigo às armas rudimentares desde tipos "antigos de espingardas, arcabuzes de mecha, trabucos desconhecidos de tão primitivos que eram" (idem, p. 477).

Há momentos em que aquela "gente bruta" parece merecer algum respeito: "bateram-se como leões esse nobre e desgraçado povo" (idem, p. 477) e o desespero de um incêndio que alcançaria muitos feridos parece ter chocado, momentaneamente, o militar diante da tragédia do inimigo no campo de batalha. Entre a foto enrijecida pela postura dos "inimigos", cabe aqui lembrar a descrição da cena de Taunay (Fig. 1), conforme a testemunha ocular:

\footnotetext{
Vi - ninguém mo contou - um paraguaiozinho gritar para um companheiro ferido também, mas de pé: “Amigo, mate-me, por favor" E o outro, acudindo à cruel imploração, desfechou-lhe um tiro à queima-roupa (Taunay, 2004, p. 477).
}

Típico do relato memorialista, depreende-se do relato supramencionado o viés dramático que pulsa na cena e coloca o narrador na posição de quem se limita a registrar o fato. Em outro momento, a mescla de temporalidades e o tempo de enunciação se confundem com o tempo do enunciado. Isto se dá quando o narrador se refere às nevralgias de fundo diabético: “Assaltaram-me em meados de 1893 e desde então não me deixaram mais" (idem, p. 482). A descrição do suplício e o calor da cama, bem como a alusão à grande banheira, não combina com a passagem pelo rio Juqueri, só então o narrador se lembra da digressão e anuncia: "Voltemos, porém, aos sucessos da campanha" (idem, p. 482).

Duque de Caxias, convertido em herói nas batalhas de dezembro de 1868 que recusa a perseguir Solano López como um capitão do mato, exigiu a mudança de liderança assumida pelo Conde D’Eu que, após a batalha de Campo Grande, começou a se mostrar irritado, displicente, melancólico e cansado das manobras do Marechal perseguido. Há até uma passagem do memorialista que insinua, de modo ambíguo, que possivelmente o Conde tenha escrito sobre seu desejo de retornar à corte, embora ele, narrador e encarregado das correspondências, não haja "deitado o olhar indiscreto sobre a correspondência do conde" (idem, p. 483), provocando no leitor, justamente o efeito contrário, que seria o de uma suspeita sobre sua real discrição. 
É certo que as memórias só poderiam ser lidas e publicadas 50 anos depois da morte de Taunay e isso se entende pelas críticas (nem sempre veladas) às desastradas resoluções que toma o Conde sobre o fornecimento de alimentos às tropas, causando muitas despesas ao erário público; fome e em consequência disso roubos; matança de cavalos para comerem a cabeça, o que causou situações extremas como suicídio e castigos exemplares a dois soldados argentinos por parte do General Osório (idem, p. $503)$.

É certo que a descrição do viajante não ficou apenas restrita ao tempo inicial da Guerra com a penetração nas fronteiras do Grosso. Exemplo disso é o relato da praga das borboletas 88. Conquista o leitor o contraste entre a beleza panamby (borboleta em guarani), que, nas matas fechadas, atacavam os animais de carga no canto dos olhos e em partes onde minasse algum líquido corporal e aí ficavam até produzirem pus e cegarem as animálias. Esse ataque revela não só os imprevistos de uma penetração invasiva dos seres humanos e equestres em territórios virgens da natureza, como pela descrição do narrador ao relatar a solução encontrada de uso da palha de milho cortada em fios finos para servir de anteparo feito aos cavalos. O episódio das borboletas 88 ocorreu na mata próxima a Curuguati que no século XXI se torna palco de uma chacina orquestrada. Entre passado ("linda povoação tão sem pretensão e agreste”; idem, p. 505) em 15 de junho de 2012 vira tragédia de Curuguaty que não era assim despretensiosa nem agreste. A Curuguaty atual marcou o palco de uma tragédia contra os colonos semterra que lutavam para reaver do Estado alguma terra como aquelas que haviam sido distribuídas ilicitamente durante a ditadura de Stroessner (mal habidas). Essa orquestração serviu ao complô que culminou no golpe parlamentar ao governo de Lugo, banido em 24 horas do cargo. Entre passado e presente está na ordem do dia bem mais próximo de nós o de uma tensão orquestrada como o complô de Curuguaty em que parecem querer repetir no Brasil o golpe de um impedimento que a figura da direção da Câmara dos deputados que, sem as cores das borboletas 88 , protagoniza a banalidade do mal, isto é, do golpe como uma praga/epidemia. O ufanismo de algumas passagens e as queixas contra a República demonstram como a escrita do emissor das memórias, quando oscila no tempo do enunciado, mostra seu anacronismo não apenas por aferrarse à monarquia, mas para criar um discurso pendular que constata uma realidade em fuga, pois lamenta o desalento sobre os embates existentes na república, sem admitir que no passado a crueldade, a fuzilaria, a degolação e os saques foram perpetrados pelo império no Paraguai, sob hegemonia brasileira, neste período mais vergonhoso da 
Guerra Guasú, hegemônica, como quando afirma: "Terminada a Guerra do Paraguai, tornou-se o Brasil, que havia desvendado tão poderosos recursos, a primeira nação da América do Sul e colocou-se à testa da hegemonia deste continente” (idem, p. 486).

Em minha experiência de leitura desse texto memorialista de um oficial monarquista, escrito pelo capitão que virou Visconde e foi senador, escrito em 1893, é preciso interpor a parcialidade com que registra de modo narcisista de sua imagem diante dos acontecimentos e mais preocupado com as dificuldades em suas relações com o Conde D’Eu e as críticas que tem por não se sentir acolhido no banquete principal do cotidiano do príncipe entre 1869/1870, o fato de não ter conseguido a patente de major do exército assume em suas memórias uma preocupação que vai tomando o espaço de quem testemunha uma perseguição ao outro da contenda. Preencher os vazios do texto em sua descontinuidade e anacronismo prefigura um palco centralizado na enunciação em que o enunciado polimorfo deixa escapar farrapos de acontecimentos, como a degola de pessoas que não ofereciam resistência praticada pelo Coronel Fidelis em Curuguati (idem, p. 505).

Como disse Pedro Nava, "escrever memórias é animar e prolongar o alter ego" (1978, p. 198) e apresentar o testemunho histórico sobre a Campanha da Cordilheira seria apenas uma faceta do memorialismo de Taunay em seu limite com a preocupação maior com sua própria imagem, polidipsia e trajetória, pois ao estar dramatizando a si próprio nessa retrospectiva deixa nítido o momento em que sua escritura sofre uma ruptura em dezembro de 1869 e o resto, ainda que possam ser lidas em cotejo com outros relatos, não passam de notas avulsas e esparsas que seriam desenvolvidas pelo autor, segundo observação de seu filho Affonso de E. Taunay.

\section{Segundo Ato - Da falcatrua bélica à arte pictórica de Cándido López (Arquivando o inédito)}

Como documento a que tive acesso recentemente e (aqui agradeço publicamente a cessão de uma carta de um ancestral do professor e amigo Henrique Finco) forma parte do material de leitura que emerge das recordações de uma família riograndense. Sua data coincide com a do acampamento de Curuzu que também inspirou um dos quadros do tenente argentino Cándido Lopez que no pós-guerra alimentava um discurso como o de B. Mitre, no dia 02 de maio de 1885, que admite na abertura de uma exposição de Cándido Lopez: "são verdadeiros documentos históricos pela fidelidade 
gráfica e contribuirão para conservar a gloriosa memória dos fatos que representam" (apud TAMOIO, 1973, p. 9).

Então, vejamos de que patamar se vê o outro flanco da frente aliada, nesta carta, até agora inédita, do bisavô de Henrique Finco, professor da UFSC, que, esclareço, não é responsável pelo modo como elaboro a leitura deste documento epistolar. Seria a carta de um militar brasileiro, um Voluntário da Pátria, que talvez fosse alferes? Josué Antonio de Araújo Quadros, que também assinava Josué Antonio Alves, escreve e data: “Acampamento no Paraguay, Forte de Curussú, 17 de outubro de 1866" (doc. FINCO, 1866). O destinatário era seu irmão (o caçula da família), Diogo de Araújo Quadros.

Há vários temas na carta que podem servir a posteriores indagações, mas aqui o que me interessa destacar é a alusão a dívidas de soldado, primo seu, do mesmo batalhão, Joaquim Barros de Araújo (Quinca), que foi ferido na guerra e voltou a Santo Antonio da Patrulha, tendo falecido no dia 14 de outubro de 1866:

\footnotetext{
Diogo, a respeito do inventário do fallecido Quinca eu nada posso arremediar pela distancia em que me acho, o que sim é que aqui tenho pago dívidas do fallecido que devia ao Tenente Coronel Dutra e mais outros officiais e de tudo tenho recibo, anda isto talvez em quatrocentos mil reis, dinheiro que tenho ganhado de meus vencimentos, logo assim Vm.ce vejão que eu não posso perder . Não mando os documentos pela razão de recear que se perca, a basta as miadas que elle fazia com os negocios é a causa disto tudo. Em Pelotas, emprestei a elle cincoenta mil reis 150:000 reis tudo isto anda por mais de quinhentos mil reis, elle quando morreu a oito para nove mezes que não recebia soldo gastando seguido isto bota longe, esperança de eu la ir tão cedo não tenho ainda mesmo que queira obter licença para chegar até lá não obtenho, por que eu não tenho padrinho estou certo que em dois mezes tinha tempo de sobra para la ir e voltar, embarcado em 15 dias vai se daqui a Porto Alegre; aqui tudo trabalha para se retirar os que tem bons padrinhos safão-se, outros tem que agüentar ate largar a casca porque isto aqui não é brincadeira, já não se faz caso da morte, porque todos os dias esta se morrendo aos punhados tanto de bala como de moléstia se em dois ataques temos tido talvez que se tenha perdido 4 a 5 mil homens, todos dias perdemos gente das balas de pessa que cahem dentro do acampamento, do forte do inimigo alcanção aos nossos (FINCO, 1866).
}

O que também informa o bisneto Henrique Finco sobre o remetente Josué Antonio Alves Quadros é que ele teria tido alguma patente (talvez de alferes) por ter conseguido recrutar outros voluntários para a guerra que seriam os escravos da fazenda que aceitavam ir para a Guerra com a promessa de que ao voltar (se é que voltassem) conseguiriam a alforria.

Além do aspecto coloquial, característica da intimidade que se torna elemento fundamental na tentativa de demonstrar carinho e afetividade à distância, a de uma oralidade só possível pela escrita, a carta manifesta um tom, tanto de desabafo do sujeito 
que sofre a injustiça por identificar uma dívida de quem está vivo e tem que pagar em nome de Quinca, após seu falecimento e que ao mesmo tempo não pode cobrar, pois está longe e impossibilitado de viajar ao Brasil para isto. Também se observa o testemunho do perigo, não só das balas inimigas como das doenças e de algum modo há uma denúncia do antigo e nada digno comportamento brasileiro que se baseia no famoso "jeitinho": o apadrinhamento no Exército que facilita a uns e dificulta aos demais o direito a licenças e outros modos de participar da guerra com diferentes tipos de ocultos respaldos.

Julio Chiavennato, em entrevista ao documentário Guerra do Brasil, a verdade sobre a Guerra do Paraguai (1987), dirigido por Sylvio Back, aborda o tema da corrupção entre o oficialato gaúcho que repassavam à corte uma lista com nomes de soldados e que, ao receber o soldo, não o repassavam e embolsavam o financiamento devido à Guarda Nacional. Assim se relata a impunidade de oficiais, alguns até heróis que, ao começar a Guerra do Paraguai, receberam mais auxílio para comprar cavalos, armas e outros apetrechos para a defesa do país. Com isto, continuaram estafando o governo central. O certo é que a Guarda Nacional não se confundia com o Exército que só foi realmente organizado com a Guerra do Paraguai e o recrutamento em janeiro de 1865 seria um capítulo à parte. Assim a região de maior experiência em ataque e defesa em todo o país, sem dúvida, era a do Rio Grande do Sul por sua posição de fronteira entre as terras espanholas e lusitanas. Também há que se explicar que os documentos da Guerra ainda continuam em posse das Forças Armadas Brasileiras, além dos troféus de guerra, há documentos paraguaios que, segundo consta, ainda não foram devolvidos pelo Brasil e muitos deles pertencentes ao período colonial. As diferentes denúncias teriam que passar para o rastreio de uma pesquisa em rede, pois o fato de o Centenário da Guerra do Paraguai ter ocorrido sob o golpe de 1964, quando o ensino superior ainda era extremamente reduzido e não termos naquela ocasião um grande rede de pesquisas e pós-graduações, pois as universidades federais estavam em formação, impediu o aprofundamento e a discussão sobre a Guerra, o que ainda hoje, no Brasil, em determinadas esferas continua a ser um tema tabu. ${ }^{3}$

O caso particular de Quinca, o militar morto que continua com dívidas por não ter recebido seu salário, evidentemente não devia ser o único caso. Em $O$ Diario de la

\footnotetext{
${ }^{3}$ No ano de 2014, em conferência de um diplomata brasileiro na UNILA, levantei o tema dos troféus e documentos saqueados do Paraguai no fim da guerra e não houve resposta pública. Ao final o conferencista disse-me que este ainda era um tema tabu entre o Itamarati e o Exército e por isso ele não havia respondido a minha questão.
} 
Campaña de las fuerzas Aliadas contra o Paraguay de León de Palleja, oficial que lutava pelo Uruguai, mas era espanhol, chegara fugido e mudara seu nome (José Pons de Ojeda) para escapar talvez de uma repatriação. Ao adotar outro nome e lutar pelo Uruguai foi um dos mais especiais testemunhos bélicos e que, ao morrer na Batalha do Boquerón (18 de Julio de 1866), deixa uma grande lacuna. A carência de uma voz que cumpria o papel de testemunha e do correspondente de guerra, o repórter que fez do testemunho um gênero bélico que tem nele um precursor. Ao redigir suas cartas com as críticas de dentro sobre a Marinha brasileira e a falta de preparo dos oficiais, além de outras atitudes descabidas para um militar e nada honradas para o exercito aliado, Palleja exibe a estética como ética, pois os equívocos resultaram em uma perda de vítimas que o própio Palleja criticou, mas não pode escapar. O cotidiano da Guerra Guasú a partir de suas cartas mereceriam não apenas a tradução e publicação ao português como um evento de reconhecimento internacional, não apenas por sua importância, como pela fundação de uma estética transterrada que o sujeito diaspórico devido a uma trajétória estrangeira acaba por se ver esquecido. A guerra, que para Palleja não era a primeira, tornava-o um sujeito cauteloso, ético e crítico no limiar entre vida e a morte com as emergências, precariedades e exclusões, como esta que lhes trago em forma de uma epístola olvidada em arquivos familiares de um combatente de Caxias do Sul no interior do Rio Grande do Sul e que aponta apenas para um limiar de algumas das tantas chispas que se necessita encontrar da guerra sul-americana que ainda nos envergonha por sua violência principalmente ao final (após o saque de Asunción), o desprezo às vítimas e ao holocausto paraguaio, merecendo ser recordada, discutida ( algo que ainda não ocorreu com a potência, a profundidade e alcance por questões políticas que marcaram o centenário no Brasil, Argentina e Uruguai. Recordála, não para excitar os imaginários revisionistas, mas para que, ao discorrer sobre como aprender a resistir à tendência a disputas bélicas no futuro que mais do que nunca continuam a ameaçar a América Latina.

\section{Entretelas de Candido López}

Das pinturas da Guerra Grande, se destaca a trajetória do tenente argentino Cándido Lopez que pintava no fronte de batalha e suas telas, de fato, não representa o fato épico, nem um documento, articula um outro limiar dos mais inesquecíveis das batalhas, pois, ataca frontalmente o ponto crucial de uma guerra, quando os corpos entram em confronto, ao minimizar dito ato em algo que esconde o sentido (Fig. 2). Nos 
quadros de Cándido Lopez não há fato glorioso, mas corpos isolados, vistos por igual, distantes como soldadinhos de chumbo que parecem brincar, ou que trabalham, ou se movem, de modo, aparentemente cotidiano em um tabuleiro, em geral aberto. Inexiste a hierarquia, há horizontalidade e as máquinas de guerra (navios encouraçados, ou monitores encomendados para a Guerra na França e na Inglaterra) ou estão distantes ou quase apagados do cenário da guerra. Não cobram importância, por não haver ostentação para esse olhar como nas outras "máquinas de pintura" (a moda francesa de quadros imensos), as máquinas dramáticas ou epifânicas como aquelas pintadas sob encomenda imperial a Victor Meirelles (Ver la Batalla de Riachuelo).

Para Cándido Lopez nada que fosse enfático ou pomposo importava em seu modo de registrar o cotidiano da arte bélica. Foi Jose Luis García, o roteirista e diretor do documentário Cándido Lopez, los campos de batalla (2005) que sintetizou em uma metonímia o principal elemento pictórico do artista argentino, ao observar os detalhes diretamente nos quadros do tenente pintor que os botões da roupa dos soldados ele pintava, mas não os olhos ou a boca do corpo de guerra. Entretanto, o sinal claro da morte se manifesta nos rostos de olhos abertos que nesta passagem fatal merecia o destaque da visão.

A partir desse detalhe seria possível deduzir que estar na guerra exige um corpo objeto, reificado, sem sentido, ou, de fato sem esses órgãos, pois os braços e as pernas se movem, mas não vale apavorar-se com o que se vê, nem a voz, ou os gritos, o corpo se transforma ao mutilar-se como parte de um conjunto, que só pode recobrar alguma humanidade, como a mirada, ao perder a vida no campo de batalha. A sua maneira, Candido Lopez reduz a guerra a um fato inevitável para o corpo que vive nela em um momento em que os países estavam criando suas pátrias com altares, heróis e hinos e lutando pelas fronteiras territoriais, Candido López pinta na oposição a guerra sem solenidade alguma.

A falta de centralidade de seus quadros, é o que parece buscar Candido Lopez, que não escolhe um foco por não pretender direcionar o modo como se contempla as ações. Deslocam-se em atos corriqueiros, em diferentes detalhes e o que se considerava no século XIX como a base pictórica que era a perspectiva renascentista, em Candido Lopez não merece a mais mínima atenção. Devido a isto sua pintura foi rechaçada por não haver compreensão dessa proposta inovadora. Só no século XX, depois de 40 anos de sua morte, graças a um crítico de arte, José Luis Pagano, que lhe incluiu em um livro sobre a pintura argentina, é que se estabeleceu a relação entre o que propunha Cándido 
Lopez e uma das técnicas - all over - de Jackson Pollok. Contrariamente à tradição ocidental de pinturas bélicas, seus campos de batalha não monumentalizava os fatos. Recorda de algum modo a Peter Bruegel? Ou de outro ao Jardin de las Delicias de Bosch? Para o passado, ou para o futuro, Cándido Lopez, com uma ou outra mão, vivia na guerra e depois dela uma vida dedicada ao ofício de criar cotidiano onde o establishment preferia ver o extraordinário.

O modo como Cándido Lopez captou a Guerra teve desdobramentos em uma das últimas obras de Augusto Roa Bastos que pode ser lida por sua intermidialidade. Em uma obra assinada por quatro escritores (Eric Nepomuceno, Omar Gadea, Alejandro Maciel e Augusto Roa Bastos, um escritor por país da Guerra Guasú), chamada Los conjurados del quilombo del Gran Chaco (2001) Roa Bastos publica um texto transgenérico - Frente a frente argentino, cujo discurso propõe uma armadilha ao leitor que pensa estar lendo um relato que, em realidade, camufla um diálogo teatral ao estilo filosófico da escola platônica que se dá entre o pintor Candido Lopez e o General Mitre. Mais que dois personagens históricos, respectivamente, apresentam-se como duas alegorias em conflito na memória da Guerra Grande: a Arte e a Guerra a configurar uma potente defesa pós-guerra de uma integração regional pacífica.

O quadro Desembarco del ejército argentino a las trincheras de Curuzú de Cándido Lopez comunica a altivez natural da fronteira de árvores de maior visibibilidade ao lado esquerdo entre troncos e ramas no primeiro plano à margem do rio que, em perfeito equilíbrio com diminutos corpos de soldados separados que caminham rumo a um bloco uníssono, seja de vegetação ao fundo ou em rota transversal aos homens que se reúnem respectivamente em colunas. $\mathrm{O}$ rio contém barcos do lado esquerdo ou esmaecidos ao fundo e em primeiro plano alguns poucos homens a cavalo. Cinco apenas. Se as árvores deixam o isolamento para se compactar ao longe, do mesmo modo atuam os corpos que vão formando os batalhões. A flora e a humanidade se repetem em uma paisagem harmônica. Tudo parece plasmar-se sem sobressaltos e a posição humana se dá verticalmente como se no ar houvera uma ordem cósmica para preparar-se. Não há pânico e tampouco se adivinha a proximidade trágica de morte. Não há peleja nem corpo inimigo visível. O momento eleito para registrar exibe um desembarque, o movimento das tropas do elemento água para a terra, o Acampamento o cotidiano da penetração aliada no Paraguai, mas tudo sem glória, rapidez ou solenidade. Um momento de formação. Não se veem bandeiras, nenhum panteão que distinga ou que lhes identifique nessa tarefa como na maioria das pinturas. Não se vê 
nem a vanguarda, nem a retaguarda, nem os oficiais, nem malas. Corpos se movem ante uma paisagem tranquila e nada parece prognosticar a mais grande batalha de Curupayti, a grande vitoria do Paraguai dez dias depois a 22 de setembro de 1866, em que entre os mais de dez mil mortos aliados o pintor se fere e perde sua mão direita, aprendendo depois a pintar com a sinistra sem perder a técnica adquirida entre as articulações de dois sentidos tão aguçados: a mirada (o visual) e o táctil em sua arte que se associa no século XX a dois novos pintores argentinos como Lindner e Laren e continua até hoje estalando faíscas em quem os vê.

Diferentemente do que pensava Bartolomé Mitre em sua resposta à invasão paraguaia de abril de 1865, "En tres dias a los cuarteles, en quince dias en campaña; en tres meses en la Asunción” (MITRE, La Nación, 21/04/1865), a guerra se arrastou durante mais de cinco anos, causando o holocausto paraguaio, além de outras sequelas econômicas, políticas e culturais de um lar sem pai.

\section{Terceiro Ato: Poética Ameríndia na fronteira com a guerra (Guataha)}

Se é pelas dimensões sensíveis ou afetivas que passam os estudos do imaginário, não há como abrir mão da performance como categoria epistemológica, pois como asseveram Bianchiotti e Orchetto:

\footnotetext{
a noção de performance permitiu às ciências sociais indagar em processos socioculturais por meio do estudo de aspectos icônicos, corporais, performáticos, volitivos e afetivos em um espaço conceitual de integração e confluência (2013, p. 122).
}

Enfatizando as corporalidades no campo das literaturas periféricas, finalizo refletindo sobre alguns rabiscos no chão do corpo emergente e que aqui figuram como limiares transterrados de uma região trinacional onde reverberam diferentes racionalidades. Como coloca Luis Cárcamo Huichante em sua reflexão sobre as emergências, se por um lado as emergências expõem vulnerabilidades e urgências do presente (que às vezes atropelam ou causam ruídos), por outro costumam indicar respostas criativas de empoderamento (CARCAMO, 2015, p. 4). Assim alguns limiares sejam discursivos, textuais ou advindos de outras práticas culturais que, pela mediação tecnológica, é possível registrar vozes como suporte, o interesse é trazer ao debate posições, atitudes e reflexões sobre a guerra na contemporaneidade.

Aqui, então, temos uma hidroelétrica que, para demonstrar o mito da destruição do mundo, endossa o dilúvio e inunda os 1.500 hectares da aldeia Jacutinga para fazê-la 
submergir no lago da represa Itaipu e transfere o contingente indígena para o Tekoha Ocoí com mais de 700 almas, às margens do lago, ou do agronegócio sem separar o Paraguai. Há tempos, da aldeia Acaraymi, saiu fugido e jurado de morte o líder Ava Guarani Guilherme Tupã Ñevangaju Rocha e a sua voz xamânica e centenária, antes do seu encantamento aos 120 anos, no último 24 de março, fala como um livro vivo, bem alto em guarani e canta e Cassemiro Centurião, em português, bem pé no chão lê e desenha na terra uma explicação sobre a Guerra Grande, sendo os dois registrados no documentário Guataha (2015), lançado agora no Brasil. São algumas das vozes emergentes apenas, a serem ouvidas como uma proposta de futuro que reúna literaturas e seus polissistemas como parte das culturas e a história, pois como diz Marshall Sallins, ao comparar uma guerra antiga, como a do Peloponeso (entre Atenas e Esparta), com outra no século XIX. Guerra da Polinésia, interpelando uma das bases da historiografia ocidental como a de Tucídides, que não liam nos conflitos as culturas em questão: "a razão disso é que, sendo povos culturalmente distintos e agindo de modos diferentes no mundo e sobre ele, será necessário conhecer seus esquemas de valor e de relações a fim de entender suas histórias" (SALLINS, 2006, p. 101). No caso da Guerra Guasú, o que sabemos do Paraguai, esse país cuja constituição de 1992 só então admite ser pluricultural e bilíngue e frente a um presente que traz os imaginários de uma guerra, contra a violência, em lugar de criar esquecimento é preciso escutar o canto do silêncio nas palavras que criam a memória sem nambrena, falcatrua e Curuzu na guerra Guasú da América do Sul. Agujevete!

\section{REFERÊNCIAS}

BERGER, Timo - "¿Qué dice un lenguaje que no se puede entender? Una entrevista con el autor paraguayo Jorge Kanese? Revista HUMBOLDT, 153; Goethe Institut, 2010, p.30-31.

BIANCIOTTI, M. C. y ORCHETTO, M. "La noción de performance y su potencialidad epistemológica en el hacer científico social contemporâneo". Tabula Rasa. Bogotá Colombia, No.19: 119-137, julio-diciembre 2013.

FINCO, Henrique (org.) - "Carta de Josué Antonio de Araújo Quadros, Forte Curussu, 17 de outubro de 1866". Transcrição de dados sobre a carta a Alai Garcia Diniz, Fpolis, 2014.

JOURDAN, E.C. Guerra do Paraguay. RJ: Typografia de Laemmert, 1890. 
MITRE, Bartolomé. La Nación Argentina. Buenos Aires: 21 de abril de 1965.

NAVA, Pedro da Silva. Beira-mar. Memórias/4. Rio de Janeiro: José Olympio, 1978.

RICOEUR, Paul. A mémoria, a história, o esquecimento. Tradução Alain François (et. al) Campinas: Unicamp, 2007.

ROA BASTOS, A. "Isla rodeada de tierra”. El correo de la UNESCO, agosto de 1977.

SÁNCHEZ, Luis Alberto - Reportaje al Paraguay, Lima: 1949.

SALLINS, Marshall. História e Cultura apologia a Tucídides. Trad. Maria Lucia de Oliveira. RJ: Jorge Zahar Editor, 2006.

TAUNAY, Visconde de - Memórias. São Paulo: Iluminuras, 2004.

\section{Anexos}

I - Figura 1 - Batalla de Acosta Nu (Paraguay)/ Batalha de Campo Grande (Brasil) $16 / 08 / 1869$ - foto dos inimigos

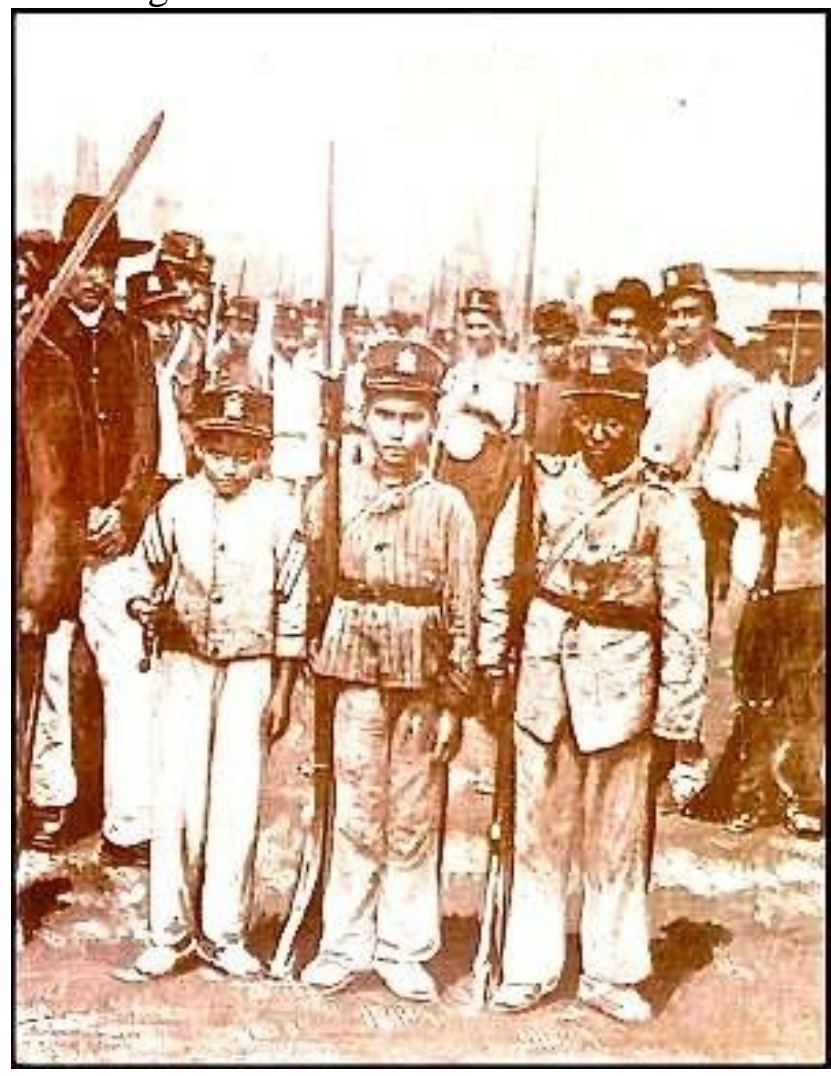

II - Figura 2 - "Desembarco del Ejército Argentino frente a las trincheras de Curuzú, el 12 de septiembre de 1866". Óleo de Cándido López. 1891. Museo Nacional de Bellas Artes 


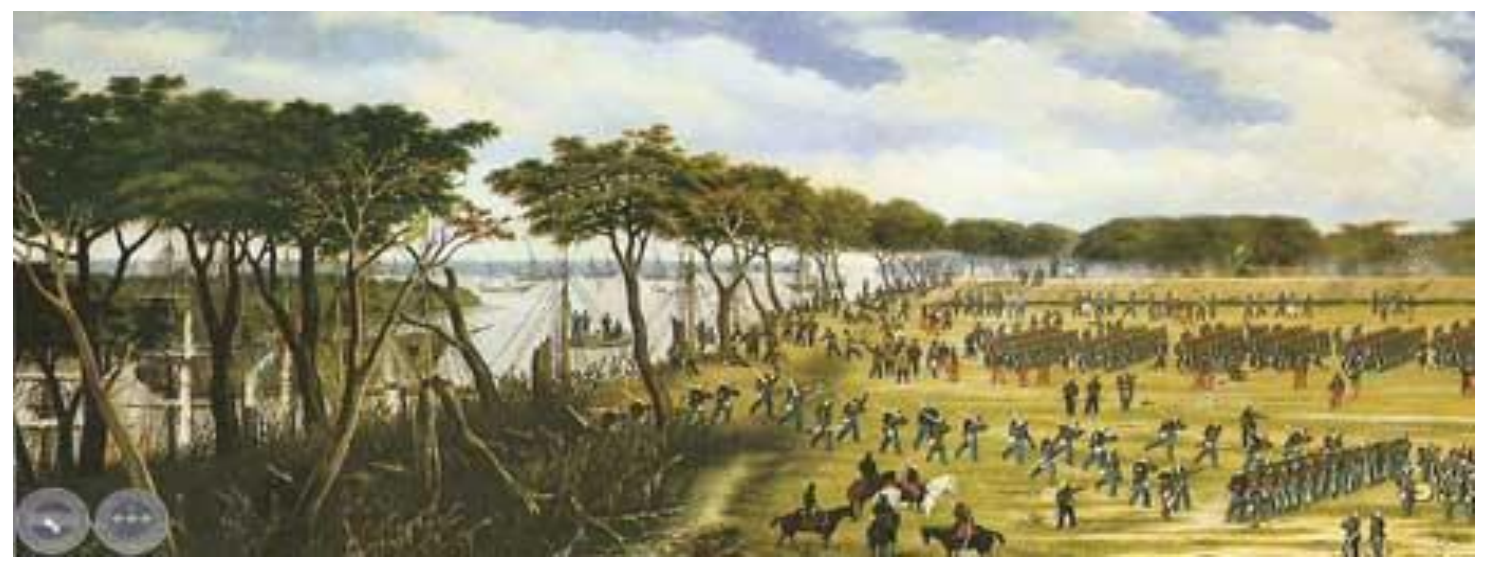

